\title{
Brazoides A-D, New Alkaloids from Justicia gendarussa Burm. F. Species
}

\author{
Luciana G. S. Souza, ${ }^{a}$ Macia C. S. Almeida, ${ }^{a}$ Telma L. G. Lemos, ${ }^{*, a}$ Paulo R. V. Ribeiro, ${ }^{b}$ \\ Kirley M. Canuto, ${ }^{b}$ Raimundo Braz-Filho, ${ }^{c, d}$ Catarina N. Del Cistia, ${ }^{e}$ \\ Carlos Mauricio R. Sant'Anna, Francisco S. Barreto ${ }^{g}$ and Manoel O. de Moraes ${ }^{g}$
}

${ }^{a}$ Departamento de Química Orgânica e Inorgânica, Universidade Federal do Ceará, 60451-970 Fortaleza-CE, Brazil

${ }^{b}$ Embrapa Agroindústria Tropical, 60511-110 Fortaleza-CE, Brazil

${ }^{c}$ FAPERJ, Departamento de Química, ICE, Universidade Federal Rural do Rio de Janeiro, 23890-000 Seropédica-RJ, Brazil

${ }^{d}$ Laboratório de Ciências Químicas, Universidade Estadual do Norte Fluminense Darcy Ribeiro, 28035-200 Campos dos Goytacazes-RJ, Brazil

${ }^{e}$ Departamento de Matemática and ${ }^{f}$ Departamento de Química, ICE, Universidade Federal Rural do Rio de Janeiro, 23894-374 Seropédica-RJ, Brazil

${ }^{8}$ Núcleo de Pesquisa e Desenvolvimento de Medicamentos (NPDM), Universidade Federal do Ceará, 60430-275 Fortaleza-CE, Brazil

Four new alkaloids, Brazoides A-D, together with three known compounds squalene, $\beta$-sitosterol and lupeol, were isolated from leaves of Justicia gendarussa. These structures were established by spectrometric techniques, mainly high-resolution electrospray ionization mass spectrometry (HRESIMS) and 1D and 2D nuclear magnetic resonance (NMR), including comparative analysis with literature values. Structural determination of the compounds, Brazoides A-D, was strengthened by molecular modeling and density functional theory (DFT) calculations to predict the NMR data and compare with the experimental NMR values of these natural products. The new compounds were tested against three human cancer cell lines (glioblastoma, prostate and colon), but none exhibited activity.

Keywords: Acanthaceae, Justicia gendarussa, alkaloids, Brazoides

\section{Introduction}

Justicia is the largest genus of Acanthaceae family, with approximately 600 species, distributed throughout the tropics and subtropics of both hemispheres, extending into the temperate regions of North America. ${ }^{1-3}$ In Brazil, this genus is represented by approximately 128 species. ${ }^{4}$ The species Justicia gendarussa Burm. F. is found in tropical and subtropical areas of Asia and India, and also in northeastern Brazil. It exhibits several biological properties, such as antioxidant, anti-arthritic, anti-inflammatory, analgesic, anti-cancer, hepatoprotective and larvicide. J. gendarussa has been used in folk medicine to treat fever, cough, aphthae, arthritis, headaches, facial paralysis, earache, bronchitis,

*e-mail: tlemos@dqoi.ufc.br liver diseases, chronic rheumatism, inflammations, vaginal discharges, dyspepsia and ocular diseases. ${ }^{5-9}$

The species of the genus Justicia have many morphological similarities among themselves, so that share some common names and medicinal indications. In Brazil J. gendarussa is known as Anador or Anador grande. ${ }^{5}$ Earlier phytochemical studies reported the presence of triterpenoids, ${ }^{9}$ steroids, ${ }^{9-11}$ flavonoides, ${ }^{11-13}$ and nitrogen compounds in its leaves. ${ }^{14,15}$

In this paper, we are describing the isolation and the structure elucidation of four new alkaloids, named Brazoides A-D (1-4), of Justicia gendarussa (Figure 1). The structures were established by spectrometric techniques, mainly high-resolution electrospray ionization mass spectrometry (HRESIMS) and 1D and 2D nuclear magnetic resonance (NMR), including comparative analysis with literature 
values. Structural determination of the compounds was strengthened by molecular modeling and density functional theory (DFT) calculations to predict the NMR data and compare with the experimental NMR values of these natural products. Cytotoxic activities in vitro of compounds were evaluated using three human cancer cell lines, SF-295 (glioblastoma), PC-3 (prostate) and HCT-116 (colon).

\section{Experimental}

\section{General experimental procedures}

Optical rotations were obtained on a JASCO P-200 polarimeter. Infrared spectra (IR) were recorded on a PerkinElmer Spectrum 1000 FT-IR spectrometer using KBr pellets. The NMR spectra were accomplished on Bruker Avance DRX-500 and Agilent VNMR-600 spectrometers. The ${ }^{1} \mathrm{H}$ and ${ }^{13} \mathrm{C}$ chemical shifts are expressed in the $\delta$ scale and were referenced to TMS through the residual solvent. HRESIMS were obtained on a Shimadzu spectrometer LCMS-IT-TOF type equipped with electrospray ionization source. Column chromatographies were performed with silica gel 60 (63-200 $\mu$ M, Vetec), Sephadex LH-20 (Pharmacia) and cartridge SPE C18 (Phenomenex). Thin layer chromatography (TLC) was performed on precoated silica gel aluminum sheets (Macherey-Nagel) with fluorescent indicator $254 \mathrm{~nm}$. The compounds were visualized by UV detection and by spraying with vanillin/ perchloric acid/EtOH solution, followed by heating. High performance liquid chromatography (HPLC) separations were carried out on a Shimadzu apparatus equipped with SPD-M20A UV-Vis detector, and a Phenomenex ${ }^{\circledR}$ Luna 5 u C18 preparative column $(250 \times 10 \mathrm{~mm})$, using a $\mathrm{H}_{2} \mathrm{O} / \mathrm{MeOH}$ solvent system as mobile phase.

\section{Plant material}

The leaves of $J$. gendarussa, were collected in the Garden of Medicinal Plants of the Federal University of

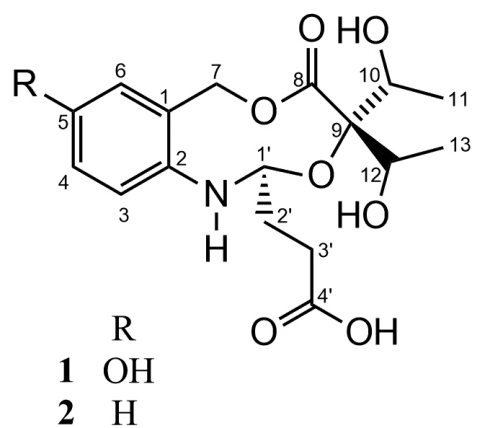

Ceará (UFC) in March 2012. A voucher specimen was identified by the botanist Edson Nunes deposited in the Herbarium Prisco Bezerra, of UFC with the number 52214.

\section{Extraction and isolation}

The dried and crushed leaves of J. gendarussa $(295.0 \mathrm{~g})$ were extracted exhaustively with ethanol at room temperature and then evaporated under reduced pressure to give $55.4 \mathrm{~g}$ of crude extract. Afterwards, this extract was subjected to removal of chlorophyll. The chlorophyll extraction was performed by dripping of water on the ethanol extract under stirring until obtaining a ethanolwater $(7: 3)$ solution. Subsequently this solution was stored at low temperature for 24 hours and then vacuum filtered, yielding a precipitate rich in chlorophyll and a free ethanol extract chlorophyll (46.0 g). ${ }^{16}$ Approximately $20.0 \mathrm{~g}$ of chlorophyll-free crude extract was subjected to column chromatography on silica gel eluted with mixtures of solvents: hexane, $\mathrm{CH}_{2} \mathrm{Cl}_{2}$, EtOAc and $\mathrm{MeOH}$ in increasing polarity, giving seven fractions. After removing the solvent, the major fraction $\mathrm{AcOEt} / \mathrm{MeOH}(50: 50, \mathrm{v} / \mathrm{v})$ eluate $(12.0 \mathrm{~g})$, was separated by silica gel column eluted with $\mathrm{CH}_{2} \mathrm{Cl}_{2}$ containing increasing percentages of $\mathrm{MeOH}$, providing eight fractions $\left(\mathrm{F}_{1}-\mathrm{F}_{8}\right)$. The fraction $\mathrm{F}_{1}(85.0 \mathrm{mg})$ was chromatographed over Sephadex LH 20 eluted with $\mathrm{MeOH}$, affording 95 fractions. Fractions 43-76 were similar in TLC and were combined to give $50.0 \mathrm{mg}$ of a mixture of compounds. Later on, this mixture was chromatographed by semi-preparative RP-18 HPLC, using $\mathrm{H}_{2} \mathrm{O} / \mathrm{MeOH}$ $(80: 20, \mathrm{v} / \mathrm{v})$ isocratic elution, and a flow of $2.3 \mathrm{~mL} \mathrm{~min}^{-1}$, to afford $\mathbf{1}(2.5 \mathrm{mg})$ and $\mathbf{2}(2.0 \mathrm{mg})$. The fraction $\mathrm{F}_{6-7}(4.0 \mathrm{~g})$ was chromatographed on a $\mathrm{C}_{18}$ cartridge eluting $\mathrm{H}_{2} \mathrm{O}$ / $\mathrm{MeOH}(50: 50, \mathrm{v} / \mathrm{v})$ resulting in 47 fractions. Subsequently, the fraction $1(615.0 \mathrm{mg})$ was subjected to a $\mathrm{C}_{18}$ cartridge eluted with $\mathrm{H}_{2} \mathrm{O} / \mathrm{MeOH}$ in gradient of increasing $\mathrm{MeOH}$ $(0-100 \%)$, resulting in 68 fractions. Fractions 4-6 were similar in TLC and were combined to give $80.0 \mathrm{mg}$ of a mixture of compounds. Then, this mixture was separated<smiles>[R]c1ccc(NC(=O)CCC(N)C(=O)O)c(COC(=O)C(O)(C(C)O)C(C)O)c1</smiles>

Figure 1. Alkaloids isolated from J. gendarussa. 
by semi-preparative RP-18 HPLC using the previous methodology, to afford $\mathbf{3}(23.0 \mathrm{mg})$ and $\mathbf{4}(13.0 \mathrm{mg})$.

\section{Calculated NMR}

The Spartan'14 software (Wavefunction, Inc.) provides new options for NMR calculations. To know which method would be better for offer values closer to the experimental, the $\mathrm{DFT}^{17}$ and the Hartree-Fock $(\mathrm{HF})^{18}$ methods were tested with reference compounds from the literature, to define which one would be the most appropriate. After these tests, DFT was the best method, chosen for this work. These ligands structures were constructed and energy-minimized first with the PM6 method. ${ }^{19}$ Then, DFT method was used for a second minimization, considering the presence of a solvent, preferably the one used in the experimental procedure, and the generation of the NMR spectra.

\section{Cytotoxic activity}

The cytotoxic activity was performed using tumor cell lines, SF-295 (glioblastoma), PC-3 (prostate) and HCT-116 (colon) (National Cancer Institute, USA). The cell lines were cultured in RPMI 1640 supplemented with $10 \%$ fetal bovine serum and $1 \%$ antibiotic, which were incubated at $37{ }^{\circ} \mathrm{C}$ and in an atmosphere containing $5 \% \mathrm{CO}_{2}$. Samples were diluted in DMSO and tested at a concentration of $5 \mu \mathrm{g} \mathrm{mL}^{-1}$. Cells were plated at a concentration of $0.1 \times 10^{6} \mathrm{cells} \mathrm{mL}^{-1}$ for strains SF-295 and PC-3 and $0.7 \times 10^{5}$ cells mL $\mathrm{mL}^{-1}$ for the strain HCT- 8 and incubated for 72 hours in an oven. Subsequently the samples were centrifuged and the supernatant was removed. Then $150 \mu \mathrm{L}$ of 3-(4,5-dimethyl2-thiazol)-2,5-diphenyl-2 $\mathrm{H}$-tetrazolium bromide (MTT) solution were added and the plates were incubated for $3 \mathrm{~h}$. The absorbance was measured after dissolution of the precipitate with $150 \mu \mathrm{L}$ of DMSO in plate spectrophotometer at $595 \mathrm{~nm}$. Cell viability was evaluated by reduction of the yellow dye (MTT) to a blue product as described by Mosmann..$^{20}$ Doxorubicin was used as a positive control.

\section{Brazoide A (1)}

Amorphous white solid; mp $199-203{ }^{\circ} \mathrm{C} ;[\alpha]_{\mathrm{D}}^{20}+16.5^{\circ}$ (c 0.1, MeOH); IR (KBr) $v_{\max } / \mathrm{cm}^{-1} 3328,2915,2851$, $1675,1603,1453,1411,1233,1083 ;{ }^{1} \mathrm{H}(600 \mathrm{MHz}$, $\mathrm{MeOH})$ and ${ }^{13} \mathrm{C}(150 \mathrm{MHz}, \mathrm{MeOH}) \mathrm{NMR}$ data, see Table 1; HRESIMS (positive mode) $\mathrm{m} / \mathrm{z}$, calcd. for $\mathrm{C}_{17} \mathrm{H}_{23} \mathrm{NO}_{8}$ $[\mathrm{M}+\mathrm{Na}]^{+}:$392.1316, found: 392.1315 .

\section{Brazoide B (2)}

Yellow resin; $[\alpha]_{\mathrm{D}}^{20}+14.43^{\circ}(\mathrm{c} 0.1, \mathrm{MeOH})$; IR $(\mathrm{KBr})$ $v_{\max } / \mathrm{cm}^{-1} 3419,2909,2847,1723,1661,1453,1463,1422$,
1245,$1068 ;{ }^{1} \mathrm{H}(600 \mathrm{MHz}, \mathrm{MeOH})$ and ${ }^{13} \mathrm{C}(150 \mathrm{MHz}$, $\mathrm{MeOH}) \mathrm{NMR}$ data, see Table 1; HRESIMS (positive mode) $\mathrm{m} / \mathrm{z}$, calcd. for $\mathrm{C}_{17} \mathrm{H}_{23} \mathrm{NO}_{7}[\mathrm{M}+\mathrm{Na}]^{+}: 376.1367$, found: 376.1362 .

\section{Brazoide C (3)}

Yellow resin; $[\alpha]_{\mathrm{D}}{ }^{20}-2.2^{\circ}$ (c $\left.0.1, \mathrm{MeOH}\right)$; IR $(\mathrm{KBr})$ $v_{\max } / \mathrm{cm}^{-1} 3364,2982,2923,1725,1646,1503,1443$, 1298,$1233 ;{ }^{1} \mathrm{H}(500 \mathrm{MHz}, \mathrm{MeOH})$ and ${ }^{13} \mathrm{C}(125 \mathrm{MHz}$, $\mathrm{MeOH}$ ) NMR data, see Table 4; HRESIMS (positive mode) $m / z$, calcd. for $\mathrm{C}_{18} \mathrm{H}_{27} \mathrm{~N}_{2} \mathrm{O}_{9}[\mathrm{M}+\mathrm{H}]^{+}: \mathrm{m} / 2415.1711$, found: 415.1738; HRESIMS (negative mode) $\mathrm{m} / z$, calcd. for $\mathrm{C}_{18} \mathrm{H}_{25} \mathrm{~N}_{2} \mathrm{O}_{9}[\mathrm{M}-\mathrm{H}]^{-}:$413.1566, found: 413.1560.

\section{Brazoide D (4)}

Yellow resin; $[\alpha]_{\mathrm{D}}{ }^{20}+14.66^{\circ}$ (c $\left.0.1, \mathrm{MeOH}\right)$; IR $(\mathrm{KBr})$ $v_{\max } / \mathrm{cm}^{-1} 3357,2972,2822,1732,1667,1624,1453,1411$, 1297,$1254 ;{ }^{1} \mathrm{H}(500 \mathrm{MHz}, \mathrm{MeOH})$ and ${ }^{13} \mathrm{C}(125 \mathrm{MHz}$, $\mathrm{MeOH}$ ) NMR data, see Table 4; HRESIMS (positive mode) $m / z$, calcd. for $\mathrm{C}_{18} \mathrm{H}_{27} \mathrm{~N}_{2} \mathrm{O}_{8}[\mathrm{M}+\mathrm{H}]^{+}$: 399.1762, found: 399.1774; HRESIMS (positive mode) $\mathrm{m} / \mathrm{z}$, calcd. for $\mathrm{C}_{18} \mathrm{H}_{25} \mathrm{~N}_{2} \mathrm{O}_{8}[\mathrm{M}-\mathrm{H}]^{-:}: 397.1616$, found: 397.1610.

\section{Results and Discussion}

Successive chromatographic columns of the EtOH extract of $J$. gendarussa leaves followed by HPLC led to the isolation of compounds 1-4. The structures of the compounds were determined using IR, NMR (1D and 2D), HRESIMS and molecular modeling.

Compound 1 was isolated as a yellow resin. The molecular formula $\mathrm{C}_{17} \mathrm{H}_{23} \mathrm{NO}_{8}$ (seven degrees of unsaturation) was deduced from quasi-molecular ion peak at $m / z 392.1315\left([\mathrm{M}+\mathrm{Na}]^{+}\right.$, calcd. $\left.m / z 392.1316\right)$, observed in the HRESIMS, in conjunction with the ${ }^{1} \mathrm{H}$ NMR (1D and $2 \mathrm{D}{ }^{1} \mathrm{H}-{ }^{-1} \mathrm{H}$ correlation spectroscopy (COSY)) spectra and ${ }^{13} \mathrm{C}$ NMR data deduced by experiments $\left(\left\{{ }^{1} \mathrm{H}\right\}\right.$ and heteronuclear single quantum correlation (HSQC)) that revealed the presence of two methyl groups, three methylenes (all sp 3 , including one oxygenated at $\delta_{\mathrm{C}} 63.0$ ), six methine carbons [three $\mathrm{sp}^{3}$ oxygenated represented by two signals at $\delta_{\mathrm{C}} 86.9\left(\mathrm{CH}-1^{\prime}\right)$ and $69.0(\mathrm{CH}-10$ and $\mathrm{CH}-12)$ and three $\mathrm{sp}^{2}$ aromatic carbons], along with quaternary carbon atoms (five $\mathrm{sp}^{2}$ carbons including two carbonyl groups at $\delta_{\mathrm{C}} 173.9$ and 176.0, one oxygenated at $\delta_{\mathrm{C}} 157.4$, one nitrogenated at $\delta_{\mathrm{C}} 135.5$ and one sp $\mathrm{sp}^{3}$ oxygenated at $\delta_{\mathrm{C}}$ 82.9) (Table 1). The absorption bands in the IR spectrum at $v_{\max } 3328,1675,1603 \mathrm{~cm}^{-1}$ showed the presence of hydroxyl and carbonyl groups.

The ${ }^{1} \mathrm{H}$ NMR spectrum showed signals attributed to aromatic hydrogens as two doublets at $\delta_{\mathrm{H}} 7.05$ 
Table 1. ${ }^{1} \mathrm{H}(600 \mathrm{MHz})$ and ${ }^{13} \mathrm{C}(150 \mathrm{MHz})$ NMR for Brazoide A (1) and Brazoide B (2), including results obtained by heteronuclear 2D shift-correlated HSQC $\left({ }^{1} J_{\mathrm{CH}}\right)$ and $\mathrm{HMBC}\left({ }^{\mathrm{n}} J_{\mathrm{CH}}, \mathrm{n}=2\right.$ and 3$)$, in $\mathrm{MeOH}-d_{4}$ as solvent. Chemical shifts $(\delta, \mathrm{ppm})$ and coupling constants $(J, \mathrm{~Hz})$ in parenthesis ${ }^{\mathrm{a}}$

\begin{tabular}{|c|c|c|c|c|c|c|}
\hline \multirow{2}{*}{ Position } & \multicolumn{3}{|c|}{1} & \multicolumn{3}{|c|}{2} \\
\hline & $\delta_{\mathrm{C}}$ & $\delta_{\mathrm{H}}(J$ in $\mathrm{Hz})$ & HMBC & $\delta_{\mathrm{C}}$ & $\delta_{\mathrm{H}}(J$ in $\mathrm{Hz})$ & HMBC \\
\hline 1 & 135.5 & - & $2 \mathrm{H}-7, \mathrm{H}-3$ & 133.9 & - & $2 \mathrm{H}-7, \mathrm{H}-5, \mathrm{H}-3$ \\
\hline 2 & 126.5 & - & H-3, H-6; H-4; $2 \mathrm{H}-7$ & 135.3 & - & $\mathrm{H}-6, \mathrm{H}-4,2 \mathrm{H}-7$ \\
\hline 3 & 116.4 & 7.09, d (8.4) & $\mathrm{H}-4$ & 128.2 & 7.32, d (7.8) & \\
\hline 4 & 115.6 & $6.82, \mathrm{dd}(2.4,8.4)$ & $\mathrm{H}-3$ & 129.0 & $7.44, \mathrm{t}(7.8)$ & H-6 \\
\hline 5 & 157.4 & - & $\mathrm{H}-6, \mathrm{H}-4, \mathrm{H}-3$ & 128.2 & $7.41, \mathrm{t}(7.8)$ & H-3 \\
\hline 6 & 116.4 & $7.05, \mathrm{~d}(2.4)$ & H-4, 2H-7 & 129.8 & 7.61, d (7.8) & $\mathrm{H}-4,2 \mathrm{H}-7$ \\
\hline 7 & 63.0 & $5.11, \mathrm{~m}$ & H-6 & 63.1 & $5.20-5.16, \mathrm{~m}$ & H-6 \\
\hline 8 & 173.9 & - & $\mathrm{H}-10 / \mathrm{H}-12,2 \mathrm{H}-7$ & 173.4 & - & $2 \mathrm{H}-7, \mathrm{H}-10, \mathrm{H}-12$ \\
\hline 9 & 82.9 & - & H-10/12, 3H-11/13 & 82.6 & - & $3 \mathrm{H}-11,3 \mathrm{H}-13, \mathrm{H}-12$ \\
\hline 10 & 69.0 & $4.00, \mathrm{~m}$ & $3 \mathrm{H}-11$ & 68.9 & 4.04, q (6.6) & $3 \mathrm{H}-11$ \\
\hline 11 & 16.2 & $1.15, \mathrm{~d}(6.6)$ & $\mathrm{H}-10$ & 16.0 & $1.16, \mathrm{~d}(6.6)$ & $\mathrm{H}-10$ \\
\hline 12 & 69.0 & $4.00, \mathrm{~m}$ & $3 \mathrm{H}-13$ & 69.1 & $3.96, q(6.0)$ & $3 \mathrm{H}-13$ \\
\hline 13 & 16.2 & $1.15, \mathrm{~d}(6.6)$ & H-12 & 16.5 & $1.14, \mathrm{~d}(6.0)$ & $\mathrm{H}-12$ \\
\hline 1 ' & 86.9 & $5.46, \mathrm{~m}$ & $\mathrm{H}-3^{\prime} \mathrm{b}$ & 86.1 & $5.45, \mathrm{~m}$ & $\mathrm{H}-3^{\prime} \mathrm{b}$ \\
\hline $2^{\prime}$ & 27.9 & $1.55, \mathrm{~m} ; 1.99, \mathrm{~m}$ & $2 \mathrm{H}-3$ & 28.2 & $2.53, \mathrm{~m} ; 2.05, \mathrm{~m}$ & $2 \mathrm{H}-3$ \\
\hline $3^{\prime}$ & 28.7 & $2.68, \mathrm{~m} ; 2.49, \mathrm{~m}$ & H-2'a & 28.8 & $2.73, \mathrm{~m} ; 2.48, \mathrm{~m}$ & H-2'a \\
\hline $4^{\prime}$ & 176.0 & - & $2 \mathrm{H}-3^{\prime}, \mathrm{H}-1^{\prime}$ & 175.9 & - & $2 \mathrm{H}-3^{\prime}$ \\
\hline
\end{tabular}

${ }^{a}$ Number of hydrogens bound to carbon atoms deduced by comparative analysis of $\left\{{ }^{1} \mathrm{H}\right\}$ - and APT- ${ }^{13} \mathrm{C}$ NMR spectra. Chemical shifts and coupling constants $(J)$ obtained of $1 \mathrm{D}{ }^{1} \mathrm{H}$ NMR spectrum. Superimposed ${ }^{1} \mathrm{H}$ signals are described without multiplicity and chemical shifts deduced by HSQC, HMBC and ${ }^{1} \mathrm{H}-{ }^{1} \mathrm{H}$ COSY spectra.

(meta-coupling, $J 2.4 \mathrm{~Hz}, \mathrm{H}-2$ ) and 7.09 (ortho-coupling, $J 8.4 \mathrm{~Hz}, \mathrm{H}-5)$, as well as double doublet at $\delta_{\mathrm{H}} 6.82($ metal ortho-coupling, $J 2.4$ and $8.4 \mathrm{~Hz}, \mathrm{H}-4$ ), compatible with trisubstituted aromatic ring. It was also observed signals corresponding to oxymethine and methyl hydrogens, among which the signal at $\delta_{\mathrm{H}} 4.00$ (integration for two hydrogens $\mathrm{H}-10$ and $\mathrm{H}-11$ ), and $\delta_{\mathrm{H}} 1.15$ (integration to six hydrogens for two methyl, $3 \mathrm{H}-11$ and $3 \mathrm{H}-13$ ), was attributed to two equivalents of hydroxy-ethyl groups confirmed by correlations revealed by ${ }^{1} \mathrm{H}-{ }^{-1} \mathrm{H}$ COSY spectrum, between $\delta_{\mathrm{H}} 4.00(\mathrm{H}-10 / \mathrm{H}-12)$ and $\delta_{\mathrm{H}} 1.15(\mathrm{H}-11 / \mathrm{H}-13)$ (Figure 2).

All proton and carbon signals were fully assigned through HSQC and heteronuclear multiple bond correlation (HMBC) spectra analyses (Table 1).<smiles>Cc1cc(O)ccc1N[C@@H](CCC(=O)O)OC(C(=O)O)(C(C)O)C(C)O</smiles>

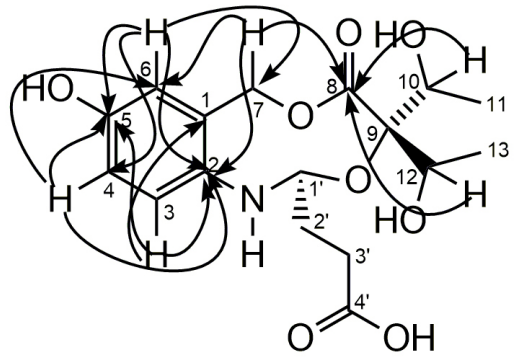

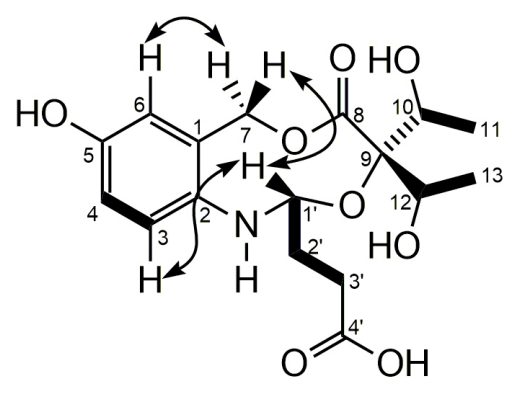

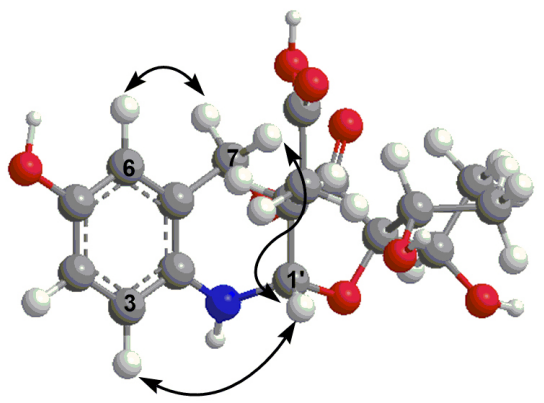

Figure 2. Structure of Brazoide A and key HMBC $(\mathrm{H} \rightarrow \mathrm{C})$, NOESY $(\mathrm{H} \leftrightarrow \mathrm{H})$ and $\mathrm{COSY}(\mathrm{H}-\mathrm{H})$ correlations. 
The HMBC cross-peaks revealed the location of the hydroxyl on carbon C-5 and the two carbonyl groups at positions C-8 and C-4', summarized in Table 1 and Figure 2. The relative configuration of $\mathbf{1}$ was deduced from analysis of nuclear Overhauser effect spectroscopy (NOESY) correlations between the signals at $\delta_{\mathrm{H}} 5.11(\mathrm{H}-7)$ and $\delta_{\mathrm{H}} 7.05(\mathrm{H}-6)$, between $\mathrm{H}-7$ and $\delta_{\mathrm{H}} 5.46\left(\mathrm{H}-1^{\prime}\right)$, and between $\mathrm{H}-1$ ' and $\delta_{\mathrm{H}} 7.09(\mathrm{H}-3)$ (Figure 1). Chemical calculations based on DFT can be used to provide reliable prediction of NMR parameters $\left({ }^{1} \mathrm{H}\right.$ and ${ }^{13} \mathrm{C}$ NMR chemical shifts). Initially, by NMR and mass spectroscopy was proposed to compound $\mathbf{1}$, three possible structures that have the same molecular formula $\left(\mathrm{C}_{17} \mathrm{H}_{23} \mathrm{NO}_{8}\right)$ and molecular weight (calcd. $m / z$ 392.1316, $[\mathrm{M}+\mathrm{Na}]^{+}$). These structures showed compatibility with all NMR data presented. Thus the prediction of NMR data by DFT was important to define the structure, which was confirmed by comparison of the NMR experimental data with the NMR results of the theoretical model (Tables 2 and 3), and comparison with data reported in the literature. ${ }^{14}$ The structure of $\mathbf{1}$ was elucidated as the new alkaloid named Brazoide A in honor of the renowned researcher Raimundo Braz-Filho.

Table 2. Comparison of ${ }^{13} \mathrm{C}$ NMR experimental data for $\mathbf{1}$ and $\mathbf{2}$, with calculated DFT-NMR

\begin{tabular}{lcccc}
\hline position & $\delta_{\text {Cexp }}(\mathbf{1})$ & $\delta_{\text {Ccalc }}(\mathbf{1})$ & $\delta_{\text {Cexp }}(\mathbf{2})$ & $\delta_{\text {Ccalc }}(\mathbf{2})$ \\
\hline 1 & 135.5 & 130.1 & 133.9 & 128.0 \\
2 & 126.5 & 140.1 & 135.3 & 146.7 \\
3 & 116.4 & 127.3 & 128.2 & 126.3 \\
4 & 115.6 & 114.2 & 129.0 & 128.4 \\
5 & 157.4 & 151.7 & 128.2 & 124.0 \\
6 & 116.4 & 116.2 & 129.8 & 130.2 \\
7 & 63.0 & 70.4 & 63.1 & 70.5 \\
8 & 173.9 & 183.0 & 173.4 & 183.2 \\
9 & 82.9 & 89.6 & 82.6 & 89.7 \\
10 & 69.0 & 71.3 & 68.9 & 71.3 \\
11 & 16.2 & 19.9 & 16.0 & 19.9 \\
12 & 69.0 & 77.8 & 69.1 & 77.7 \\
13 & 16.2 & 21.2 & 16.5 & 21.1 \\
1 & 86.9 & 90.8 & 86.1 & 90.6 \\
2 & 27.9 & 36.4 & 28.2 & 36.3 \\
3 & 28.7 & 25.3 & 28.8 & 25.3 \\
4 & 176.0 & 180.6 & 175.9 & 180.6 \\
\hline
\end{tabular}

Compound 2 (Brazoide B) was obtained as a yellow resin, and was assigned the molecular formula $\mathrm{C}_{17} \mathrm{H}_{23} \mathrm{NO}_{7}$ corresponding to molecular quasi-molecular ion peak at $m / z 376.1362\left([\mathrm{M}+\mathrm{Na}]^{+}\right.$, calcd. $m / z$ 376.1367), observed in the HRESIMS, in conjunction with the ${ }^{13} \mathrm{C}$ NMR data
Table 3. Comparison of ${ }^{1} \mathrm{H}$ NMR experimental data for $\mathbf{1}$ and $\mathbf{2}$, with calculated DFT-NMR

\begin{tabular}{lcccc}
\hline position & $\delta_{\text {Hexp }}(\mathbf{1})$ & $\delta_{\text {Hcalc }}(\mathbf{1})$ & $\delta_{\text {Hexp }}(\mathbf{2})$ & $\delta_{\text {Hcalc }}(\mathbf{2})$ \\
\hline 3 & $7.09, \mathrm{~d}(8.4)$ & 6.49 & $7.32, \mathrm{~d}(7.8)$ & 6.66 \\
4 & $6.82, \mathrm{dd}$ & 6.02 & $7.44, \mathrm{t}(7.8)$ & 7.07 \\
& $(2.4,8.4)$ & & & \\
5 & & & $7.41, \mathrm{t}(7.8)$ & 6.96 \\
6 & $7.05, \mathrm{~d}(2.4)$ & 6.32 & $7.61, \mathrm{~d}(7.8)$ & 6.87 \\
7 & $5.11, \mathrm{~m}$ & $4.99,5.42$ & $5.20-5.16, \mathrm{~m}$ & $5.03,5.44$ \\
10 & $4.00, \mathrm{~m}$ & 3.66 & $4.04, \mathrm{q}(6.6)$ & 4.19 \\
11 & $1.15, \mathrm{~d}(6.6)$ & 1.10 & $1.16, \mathrm{~d}(6.6)$ & 1.31 \\
12 & $4.00, \mathrm{~m}$ & 4.19 & $3.96, \mathrm{q}(6.0)$ & 3.66 \\
13 & $1.15, \mathrm{~d}(6.6)$ & 1.32 & $1.14, \mathrm{~d}(6.0)$ & 1.11 \\
1 & $5.46, \mathrm{~m}$ & 5.95 & $5.45, \mathrm{~m}$ & 6.04 \\
2 & $1.55, \mathrm{~m} ;$ & $1.62,2.63$ & $2.53, \mathrm{~m} ;$ & $2.67,1.68$ \\
& $1.99, \mathrm{~m}$ & & $2.05, \mathrm{~m}$ & \\
3 & $2.68, \mathrm{~m} ;$ & $2.15,2.74$ & $2.73, \mathrm{~m} ;$ & $2.76,2.18$ \\
& $2.49, \mathrm{~m}$ & & $2.48, \mathrm{~m}$ & \\
\hline
\end{tabular}

(Table 1). Spectroscopic data of $\mathbf{2}$ showed to be very similar to $\mathbf{1}$ (Table 1), but the former one had a different pattern of NMR signals in the aromatic region and the absence of the hydroxylated aromatic carbon signal in the ${ }^{1} \mathrm{H}$ and ${ }^{13} \mathrm{C}$ NMR spectra, respectively. The structure of this compound was confirmed by 2D NMR and the comparison with results of theoretical models (Tables 2 and 3).

Compound 3, a yellow resin, gave the molecular formula $\mathrm{C}_{18} \mathrm{H}_{26} \mathrm{~N}_{2} \mathrm{O}_{9}$ from its positive-mode HRESIMS $m / z 415.1738\left([\mathrm{M}+\mathrm{H}]^{+}\right.$calcd. $m / z$ 415.1711), and negative-mode HRESIMS $m / z 413.1560\left([\mathrm{M}-\mathrm{H}]^{-}\right.$calcd. $m / z$ 413.1566). The NMR spectra of $\mathbf{3}$ (Table 4 ) also showed many similarities with the compound $\mathbf{1}$, but it was observed an additional signal of a carbonyl carbon at $\delta_{\mathrm{C}} 174.0\left(\mathrm{C}-5^{\prime}\right)$. This signal was not observed in the ${ }^{13} \mathrm{C}$ NMR spectrum, but the HMBC cross-peak between $\delta_{\mathrm{H}} 3.67\left(\mathrm{H}^{-} 4^{\prime}\right)$ and $\delta_{\mathrm{C}} 174.3$ (C-5') revealed the presence of the carbonyl group, and has been confirmed by HRESIMS. The analyzed spectroscopic data and comparison with data from the literature ${ }^{14}$ and previously characterized compounds, allowed to identify the compound $\mathbf{3}$ named Brazoide $\mathrm{C}$.

Compound 4, a yellow resin, gave the molecular formula $\mathrm{C}_{18} \mathrm{H}_{26} \mathrm{~N}_{2} \mathrm{O}_{8}$ from its positive-mode HRESIMS $\mathrm{m} / \mathrm{z} 399.1774\left([\mathrm{M}+\mathrm{H}]^{+}\right.$calcd. $\left.\mathrm{m} / \mathrm{z}, 399.1762\right)$, and negative-mode HRESIMS $m / z 397.1610\left([\mathrm{M}-\mathrm{H}]^{-}\right.$calcd. $m / 2$ 397.1616). Compound 4 also showed to be very similar to those compounds described earlier. In comparison to $\mathbf{3}$ (Table 4), the only difference observed in the NMR spectra was the absence of the hydroxyl signals at C-5. Thus, the compound $\mathbf{4}$ was assigned as being Brazoide D. Also 
Table 4. ${ }^{1} \mathrm{H}(500 \mathrm{MHz})$ and ${ }^{13} \mathrm{C}(125 \mathrm{MHz})$ NMR for Brazoide C (3) and Brazoide D (4), including results obtained by heteronuclear 2D shift correlated HSQC $\left({ }^{1} J_{\mathrm{CH}}\right)$ and $\mathrm{HMBC}\left({ }^{\mathrm{n}} J_{\mathrm{CH}}, \mathrm{n}=2\right.$ and 3$)$, in $\mathrm{MeOH}-d_{4}$ as solvent. Chemical shifts $\left(\delta\right.$, ppm) and coupling constants $(J, \mathrm{~Hz})$ in parenthesis ${ }^{\mathrm{a}}$

\begin{tabular}{|c|c|c|c|c|c|c|}
\hline \multirow{2}{*}{ Position } & \multicolumn{3}{|c|}{3} & \multicolumn{3}{|c|}{4} \\
\hline & $\delta_{\mathrm{C}}$, type & $\delta_{\mathrm{H}}(J$ in $\mathrm{Hz})$ & HMBC & $\delta_{\mathrm{C}}$, type & $\delta_{\mathrm{H}}(J$ in $\mathrm{Hz})$ & HMBC \\
\hline 1 & 133.8 & - & H-7, H-3, H-4 $\left({ }^{4} J\right)$ & 131.8 & - & $\mathrm{H}-4, \mathrm{H}-3$ \\
\hline 2 & 128.8 & - & H-3, H-7, H-6, H-4 & 137.5 & - & H-6, H-7, H-4 \\
\hline 3 & 129.7 & $7.17, \mathrm{~d}(8.5)$ & & 127.8 & $7.48, \mathrm{~d}(7.5)$ & H-5 \\
\hline 4 & 116.9 & $6.78, \mathrm{dd}(2.8,8.5)$ & H-6 & 130.4 & $7.36, \mathrm{t}(7.5)$ & H-6 \\
\hline 5 & 157.4 & - & H-6, H-4, H-3 & 127.5 & $7.36, \mathrm{t}(7.5)$ & H-3 \\
\hline 6 & 118.1 & $6.93, \mathrm{~d}(2.8)$ & H-4, H-7 & 131.6 & $7.50, \mathrm{~d}(7.5)$ & H-7, H-5 \\
\hline 7 & 65.4 & $5.11, \mathrm{~s}$ & H-6, H-3 $\left({ }^{4} J\right)$ & 65.5 & $4.83, \mathrm{~s}$ & H-6 \\
\hline 8 & 175.5 & - & H-7, H-10/12 & 175.5 & - & H-7, H-10/12 \\
\hline 9 & 84.5 & - & H-10/12, 3H-11/13 & 84.5 & - & $\mathrm{H}-10 / 12,3 \mathrm{H}-11 / 13$ \\
\hline 10 & 70.6 & 4.03, q (6.0) & H-11 & 70.5 & $4.03, \mathrm{~m}$ & $\mathrm{H}-11$ \\
\hline 11 & 17.8 & $1.15, \mathrm{~d}(6.0)$ & $\mathrm{H}-10$ & 17.8 & $1.14, \mathrm{~d}(6.3)$ & $\mathrm{H}-10$ \\
\hline 12 & 70.6 & $4.03, \mathrm{q}(6.0)$ & H-13 & 70,5 & $4.03, \mathrm{~m}$ & H-13 \\
\hline 13 & 17.8 & $1.15, \mathrm{~d}(6.0)$ & $\mathrm{H}-12$ & 17.8 & $1.14, \mathrm{~d}(6.3)$ & $\mathrm{H}-12$ \\
\hline 1 ' & 174.8 & - & H-2', H-3' & 174.5 & - & H-3', H-2', H-4' \\
\hline $2^{\prime}$ & 33.4 & $2.62, \mathrm{t}(7.0)$ & H-3', H-4' & 28.1 & $2.67, \mathrm{t}(7.0)$ & H-3', H-4' \\
\hline $3^{\prime}$ & 28.1 & $2.20, \mathrm{~m}$ & H-2', H-4' & 33.6 & $2.20, \mathrm{~m}$ & H-2', H-4' \\
\hline 4 ' & 55.8 & $3.67, \mathrm{t}(5.2)$ & H-3', H-2' & 55.8 & $3.66, \mathrm{t}(5.5)$ & H-3', H-2' \\
\hline 5, & 174.3 & - & H-4' & 174.3 & - & H-4' \\
\hline
\end{tabular}

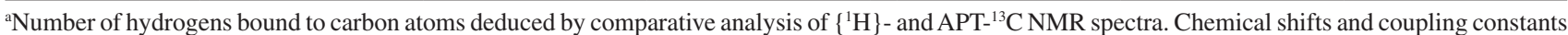
$(J)$ obtained of $1 \mathrm{D}{ }^{1} \mathrm{H}$ NMR spectrum. Superimposed ${ }^{1} \mathrm{H}$ signals are described without multiplicity and chemical shifts deduced by HSQC, HMBC and ${ }^{1} \mathrm{H}-{ }^{-} \mathrm{H}-\mathrm{COSY}$ spectra.

isolated were the three known compounds, squalene, ${ }^{21}$ lupeol ${ }^{22}$ and the mixture of $\beta$-sitosterol and stigmasterol. ${ }^{23}$

Compounds Brazoides A-D were subjected to cytotoxicity tests against three strains, SF-295 (glioblastoma), PC-3 (prostate) and HCT-116 (colon), however none of the compounds showed activity against cell lines tested.

\section{Conclusions}

In this work four new alkaloides (1-4) were isolated from the EtOH extract of leaves of J. Gendarussa Burm. F. in addition to a three known compounds. The alkaloids did not show satisfactory results when subjected to cytotoxicity testing.

\section{Supplementary Information}

The supplementary information is available free of charge on the http://jbcs.org.br as a PDF file.

\section{Acknowledgments}

The authors thank CNPq/CAPES/PRONEX/FUNCAP for the fellowships and financial support. We also thank to
CENAUREMN, of the Universidade Federal do Ceará for the NMR data, and to Embrapa Agroindustria Tropical-CE for NMR and high-resolution mass spectra.

\section{References}

1. Corrêa, G. M.; Alcântara, A. F. C.; Braz. J. Pharmacog. 2012, $22,220$.

2. Wasshausen, D. C.; Brittonia 2002, 54, 286.

3. Kottaimuthu, R.; Phytotaxa 2015, 213, 70.

4. Braz, D. M.; Phytotaxa 2015, 236, 184.

5. Oliveira, A. F. M.; Andrade, L. H. C.; Acta Amaz. 2000, 30, 569.

6. Sonal, P.; Maitreyi, Z.; Asian J. Tradit. Med. 2011, 6, 61.

7. Senthilkumar, N.; Varma, P.; Gurusubramanian, G.; Parasitol. Res. 2009, 104, 237.

8. Bhagya, N.; Chandrashekar, K. R.; Asian J. Pharm. Clin. Res. 2013, 6, 100.

9. Uddin, S.; Sinha, S.; Hossain, A.; Kaisar, A.; Hossain, K.; Rashid, M. A.; Dhaka Univ. J. Pharm. Sci. 2011, 10, 53.

10. Bhagya, N.; Chandrashekar, K. R.; Kalluraya, B.; Chem. Nat. Compd. 2013, 49, 972.

11. Bachheti, R. K.; Pandey, D. P.; Joshi, A.; Rana, V.; Int. J. ChemTech Res. 2011, 3, 244.

12. Prajogo, E. W. B.; Guliet, D.; Queiroz, E. F.; Wolfender, J. 
L.; Cholies, Z. N.; Aucky, H.; Hostettmann, K.; Folia Med. Indonesiana 2009, 45, 28.

13. Wahi, S. P.; Wahi, A. K.; Kapoor, R.; JRIM 1974, 9, 65.

14. Kiren, Y.; Deguchi, J.; Hirasawa, Y.; Morita, H.; Prajogo, B.; J. Nat. Med. 2014, 68, 754.

15. Chakravarty, A. K.; Dastida, R. P. P. G.; Pakrash, S. C.; Tetrahedron 1982, 38, 1797.

16. Ferri, P. H. In Plantas Medicinais: Arte e Ciência - Um Guia de Estudo Interdisciplinar; Di Stasi, L. C., ed.; Editora UNESP: São Paulo, p. 129.

17. Hohenberg, P.; Kohn, W.; Phys. Rev. B 1964, 136, 864.

18. Hartree, D. R.; The Calculation of Atomic Structure; Wiley: New York, USA, 1957.
19. Stewart, J. J. P.; J. Mol. Model. 2007, 13, 1172.

20. Mosmann, T.; J. Immunol. Methods 1983, 65, 55.

21. Cursino, L. M. C.; Mesquita, A. S. S.; Mesquita, D. W. O.; Fernandes, C. C.; Pereira Júnior, O. L.; Amaral, I. L.; Nunez, C. V.; Acta Amaz. 2009, 39, 171.

22. Silva, F. O.; Oliveira, I. R.; Silva, M. G. V.; Braz-Filho, R.; Quim. Nova 2010, 33, 1874.

23. Souza, A. D. L.; Rocha, A. F. I.; Pinheiro, M. L. A. B.; Andrade, C. H. S.; Galotta, A. L. A. Q.; Santos, M. P. S. S.; Quim. Nova 2001, 24, 439.
Submitted: August 18, 2016

Published online: November 4, 2016 